\title{
From Mistrust to Solidarity or More Mistrust?
}

\author{
Russia's Migration Experience \\ in the International Context
}

\author{
Dmitry V. Poletaev
}

\begin{abstract}
There is not much solidarity with migrants in major host countries and conditions for it are deteriorating. The purpose of this work is to try and assess prospects for such solidarity in those countries and specific conditions for it in Russia. Labor migrants in Russia make up the bulk of migration flows, but they have minimal opportunity for support and have to strengthen their "parallel" communities, hoping for help only from their families, and avoid as much as they can interaction with the local population, even with people of the same faith. Such estrangement leads, among other things, to the radicalization of migrants. On the other hand, Russians have long been gripped by fear of
\end{abstract}

\section{Dmitry V. Poletaev, PhD in Economics}

Institute of Economic Forecasting of the Russian Academy of Sciences, Moscow, Russia

Leading Research Fellow;

Migration Research Center, Director

ORCID 0000-0002-0255-8716

Researcher ID J-7630-2018

SPIN RSCI: 8466-0807

RSCI AuthorID: 411493

E-mail: dmitrypoletaev@yandex.ru; poletaev3@gmail.com

Tel.: +7 499 124-2561

Address: 47 Nakhimovsky Prospect, Moscow 117418, Russia

This article is an expanded and revised version of the paper written for the Valdai International

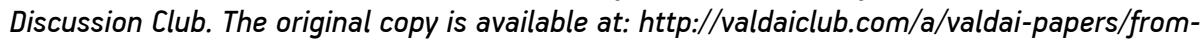
mistrust-to-solidarity/ 
migrants due to the absence of comprehensive and specially funded adaptation and integration programs for migrants in the country. The authorities' work with migrants' associations in Russia has so far been largely ineffective. At the same time, Russian non-governmental organizations have some experience of direct work with migrants, and research organizations, including NGOs, are quite efficient at assessing migration processes. Meanwhile, the government is updating its migration policy to encourage people to come to Russia, which is creating a positive background for stimulating solidarity with migrants.

Keywords: immigration, labor migration, solidarity with immigrants, migrant policy.

\section{INTRODUCTION}

The ease of transportation and communication in the modern world makes it possible to quickly deliver potential migrants to countries that they previously could only see on their television screens, hear about from family and friends living and working there, or read about in glossy magazines. A new era has dawned, different from anything humanity has ever experienced, and as the world becomes increasingly open to migration, the seeming simplicity of changing status, workplace and place of residence becomes all the more tempting. Migration contributes to "inclusive growth and sustainable development" (UN, 2016). Unfortunately, "migration without borders" (see a book with the same title, a collective work which substantiates the economic attractiveness of this development strategy (Pécoud, 2007)), once regarded as a promising strategy for the future, is increasingly viewed as an undesirable outcome by a significant number of people in host countries (Poletaev, 2010; Poletaev, 2019), and migrants can expect to find solidarity mainly among fellow migrants and left-wing parties.

The freedom of movement and the freedom to choose a place of residence can be ranked among the category of freedoms which, as part of the Global Commons, have been restricted to varying degrees at the level of communities, states, and international associations. Such restrictions have produced, and will continue to produce, a variety 
of migration conflicts both at the level of internal and international migration, due to differences in economic development, environmental situation, armed conflicts, and demographic pressure/depopulation, as well as other factors. In these circumstances, restrictions on migration in the countries of origin and host countries and regions may be justified by the interests of the countries themselves or their governments, but in reality, such restrictions are not insurmountable even in authoritarian and totalitarian systems.

Major host countries have been tightening their migration policies at the state level for several years. But they also have civil society institutions which support solidarity with migrants. The author believes that although there is little solidarity with migrants in Russia, EU countries, and the United States, conditions for developing it differ substantially.

There are certain factors that could encourage solidarity with migrants among Russian people, even though it must be said for the sake of justice that they are not always so obvious to them. Let us take a look at the main motives which can be divided into personal and general ones (Poletaev, 2014a; Zaionchkovskaya et al, 2014a).

Personal motives are as follows:

- Most labor migrants come to Russia from former Soviet republics, which share the same language, culture and history with Russian people who also have many family ties in those countries;

- Labor migrants work at small Russian enterprises, help to keep them running, and provide inexpensive services to the local population, thus finding a niche for their own employment (taxi, repairs, summer house construction, housework);

- A considerable number of Russians who worked as shuttle traders in the 1990s and traveled to Poland and China could personally experience the hardships of migration and acquired experience similar to that of current labor migrants in Russia;

- Women in Russia can work, build their career and study if they use migrants for housework, sharing some of the daily chores with them (taking care of children, elderly people, cleaning, etc.); 
- Some of the Russians are former migrants who have received Russian citizenship;

General and more global motives include the following:

- The influx of migrants seeking permanent residence in Russia allows the country to maintain its demographic potential and make up for the shortage of local residents of productive age whose number keeps decreasing;

- In the Russian Empire and the Soviet Union all Russian cities grew at the expense of internal migrants, including those from regions which with time became independent countries. In modern Russia cities have been growing due to internal migration from Russian regions and external migration from former Soviet republics.

These factors are not subject to broad public discussion and are rarely mentioned in mass media in Russia, and for this reason are barely regarded by society as a reason for solidarity with migrants.

\section{METHODS}

The article uses data from the Migration Research Center, the author's personal studies, analytical materials from the World Bank, ILO, IOM, OSCE, Carnegie Endowment, Russia's sociological Levada Center, the Russian International Affairs Council, Russian and foreign human rights and research organizations, as well as Russian and foreign media publications. It also uses data from recent Russian migration surveys, including those carried out by the Migration Research Center headed by the author, as well as his study titled "Russian Labor Market Analysis for Effective Employment of Labor Migrants from Kyrgyzstan and Tajikistan" (Poletaev, et al., 2016), which was conducted with the support of the AUCA Tian Shan Policy Center. The questioning conducted as part of the survey covered 101 labor migrants from Tajikistan and Kyrgyzstan aged 15-60 (501 respondents were questioned in Moscow, including 348 men and 153 women; 250 in St. Petersburg, including 175 men and 75 women; 250 in Yekaterinburg, 
including 182 men and 68 women). On the whole, $70.4 \%$ of male and $29.6 \%$ of female respondents participated.

The focus in studying solidarity with migrants in Russia was on external migrants (hereinafter referred to as labor migrants) who make up the bulk of migration flows coming to Russia.

\section{MIGRATION RESTRICTIONS IN HOST COUNTRIES: NEW EXPERIENCE OF MISTRUST}

In economically developed countries with aging populations that have been taking in migrants for a while now, right-wing parties advocating greater restrictions on migration are gaining more supporters, despite the fact that both the governments and the expert community that influences migration policy recognize that migration is an important resource (in economic, demographic, and geopolitical terms). The explosive growth in the number of refugees in 2015 served as a catalyst for this process in Europe. Back then, the countries of the Visegrad Group-Poland, the Czech Republic, Slovakia, and Hungary-gradually came to outright rejection of the mandatory European quotas and redistribution of refugees within the EU (Dudina, 2018), while the UK's exit from the EU following the 2016 referendum was caused, among other things, by the British being reluctant to provide benefits and social housing to immigrants who have lived in their country for less than four years (BBC, 2015).

The enthusiasm of EU residents, who welcomed the refugees and, in 2015-2016, showed remarkable examples of solidarity with them (Bershidsky, 2017), gradually faded, and by 2017-2018 gave way to fears that their excessive numbers had become a challenge to the established pan-European migration system. The real state of politics today includes the fact that Alternative for Germany is making a serious bid to become the third most influential party in the country, Lega Nord (the Northern League) in Italy gained $17.5 \%$ of vote in the March 4, 2018 elections and became one of the two parties of the ruling coalition (Dunaev, 2018), and the Austrian Freedom Party was involved in forming the government in 2017 (Klimovich, 2017). 
Donald Trump's victory in the 2016 U.S. presidential election on a platform of tighter migration policy and the election of India's Prime Minister Narendra Modi in 2014 (Mirzayan, 2014), considered a leader of the "Saffron" Indian nationalists who believe that Muslims have no place in India and openly declare in the slogan of their party that nationalism is their "inspiration" (Strokan, 2014), clearly indicate that the increased popularity of nationalist parties and slogans and the support by a considerable part of the constituency for immigration policy restrictions is not a purely European development.

Migration systems in the EU and the United States, where nonstate migration policy actors have a significant potential for inspiring solidarity with migrants, are experiencing growing resistance to such solidarity from the state due to recent changes and the election of a large number of conservative politicians who advocate migration policy restrictions (Poletaev, 2019).

Despite the fact that parties and associations advocating more restricted migration policies are gaining popularity across the world, the possibility of free movement remains an undisputed value (Baruah, 2006) $)^{1}$, and host countries use it to derive considerable economic benefits, overcome their demographic challenges, and strengthen their geopolitical influence. The equality of human society, implied by the idea of Global Commons, also means equal access to global goods and the right to migrate.

Russia's state migration policy has rather been restraining migrantphobia since 2014 (Poletaev, 2014a; 2018b), but with weak civil society non-state migration policy actors could not do much to encourage

The Treaty on European Union provides for the freedom of movement for labor migrants from EU states (but it allows temporary restrictions on the movement of citizens from countries that have been admitted to the EU recently or are in the process of admission) and prohibit discrimination of such persons by nationality in terms of employment, labor remuneration and working conditions, including social security. Labor migrants enjoy blanket protection provided by the Organization of American States (OAS), which adopted the American Declaration of the Rights and Duties of Man in 1948 (OAS, 1948) and the American Convention on Human Rights of 1969 (Pact of San José) (OAS, 1969). These documents guarantee freedom from discrimination. The Treaty on the Eurasian Economic Union declares the freedom of movement for the EEU citizens between their countries as one of the priorities. 
solidarity with migrants. However, non-state migration policy actors have built positive practices of working with migrants and have the potential for strengthening solidarity with them in both Russian society and the Eurasian migration system (Ivakhnyuk, 2008) as a whole.

Russia is one of the major host countries and has rather liberal migration legislation. For example, its latest Migration Policy Concept up to 2025 (Ukaz, 2018) aims to stimulate immigration (Ivakhnyuk, 2018). This may provide the basis for creating a more positive information background for building greater solidarity with migrants in Russia.

In real life, there are still considerable bureaucratic barriers which complicate the movement of people both to Russia and inside Russia (registration at the place of residence) and restrict the naturalization of refugees ${ }^{2}$ (Poletaev, 2014a), especially from countries with which Russia has a visa regime (difficulty of acquiring the status of refugee and subsequently Russian citizenship). In Russia, solidarity with migrants in not a priority and civil society institutions play a secondary role in forming migration policy. Nevertheless, Russia has developed certain practices for building solidarity with migrants and can succeed in doing so even despite plans to update the state migration policy (Ukaz, 2018; Solovyov and Samokhina, 2018).

\section{MIGRANTS IN RUSSIA: A WALL OF DOUBLED ALIENATION}

Over the past decade, external labor migration to Russia has undergone significant changes that directly affect relations between Russians and migrant workers from other countries (Zaionchkovskaya, et al., 2011; Poletaev, 2017; Poletaev, 2018a; Poletaev, 2018b): instead of residents of large cities, people from small towns and villages are now coming to Russia; the education level of migrants is low as schools are few and far between in rural areas; most new migrants are poorer than in the previous years; cultural differences between the newly arriving migrants and Russians are growing, including in terms of religion and language; the share of migrant workers from Central Asia is on the

2 Refugees from Ukraine were received bypassing the main refugee status procedures through temporary asylum mechanism and the program for accommodation of compatriots. 
rise, and they have begun to form communities in Russia; more female migrants and migrants with families are also coming to Russia.

The already tangible lack of unity in Russian society is further aggravated by distrust between migrants from other countries and Russians (Poletaev, 2018b). Even though such distrust rarely escalates into open hostility, one can speak of the parallel existence of two separate worlds: the world of Russians and the world of migrants (Tyuryukanova, 2009). Mutual distrust and growing alienation go hand-in-hand with the emergence of boundaries that resemble glass walls through which both sides can see each other but rarely interact.

\section{THE GLASS WALL BUILT BY FOREIGN MIGRANT WORKERS}

The mutual assistance that foreign migrant workers (especially from Central Asia) in Russia provide to each other has over time led to the emergence of a number of institutions that formed the basis for "parallel" migrant communities springing up in Russian cities (Poletaev, 2016b; Demintseva and Peshkova, 2014). Some examples follow below.

- There is a network of ethnic eateries (Uzbek, Kyrgyz, and Tajik) not only on central streets of Russian cities, such as Chaikhona No. 1, but unassuming backstreet dives that cater mostly for migrants.

- There are also athletic clubs where migrant coaches give classes in various sports and martial arts to migrant students (typically, Kyrgyz).

- A network of migrant outpatient clinics has emerged in Moscow, where doctors (both Russian citizens of foreign origin and migrant employees) provide medical services to migrant workers and use the languages of Central Asian countries to communicate. Access to such medical centers is open to Russians as well, but migrant workers form the bulk of their patients (Kashnitsky and Demintseva, 2018).

- Informal migrant services have been created to address issues such as registration at the place of residence, obtaining work permits, and other issues that every labor migrant in Russia is confronted with. Such services are often based on corrupt 
and even criminal ties between shady dealers from diaspora communities and corrupt representatives of Russian law enforcement agencies and the authorities (Poletaev, 2016b).

The emergence of parallel migrant communities in Russian society represents a major challenge for the future of Russia. The crisis of trust in Russian society is further exacerbated by feelings of alienation between foreign migrant workers and local residents. Long-term studies of migration to Russia (Poletaev, 2016a, Poletaev, 2016c; Poletaev, 2017; Zaionchkovskaya, et al., 2014b; Mukomel, 2012) show that migrant workers count on help only from family and friends. This is especially true of migrant workers from Central Asia. A 2016 survey (Poletaev, et al., 2016) conducted among migrant workers from Tajikistan and Kyrgyzstan revealed that in the overwhelming majority of cases they rely on help from family, friends, and fellow migrant workers from the same country of origin.

Fig 1. The Distribution of Respondents by Where They Seek Help, \% $(2016, \mathrm{~N}=1001)$

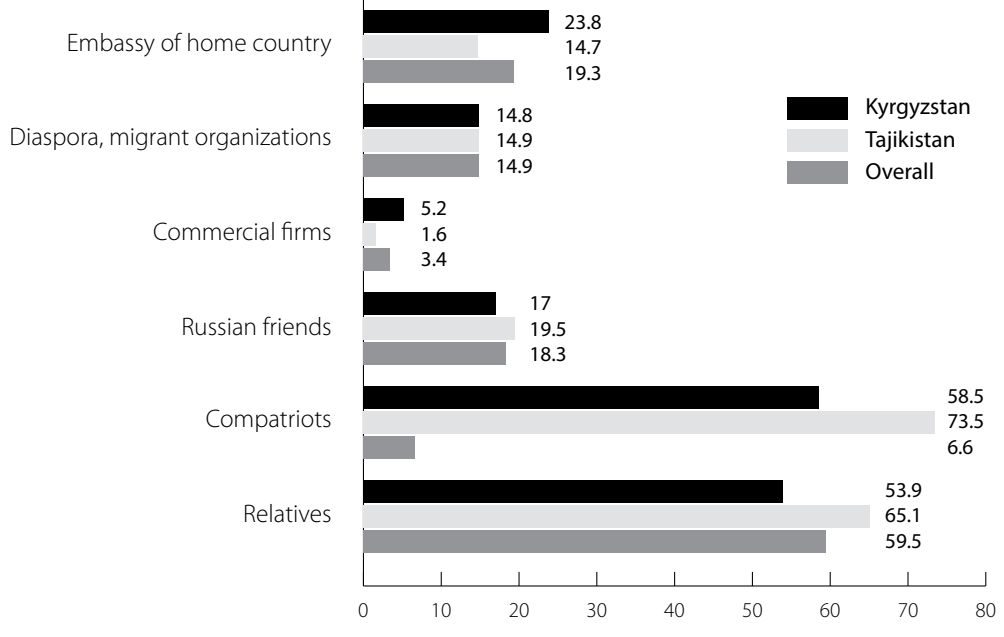

Source: Poletaev, et al., 2016

Over decades of living in Russia, migrant workers almost never have face-to-face interaction with Russians as part of their daily lives. 
From year to year, migration studies in Russia show minimal levels of interaction with the locals (Fig. 2).

Fig 2. Distribution of Respondents by Who They Interact With, $\%(2016, \mathrm{~N}=1001)$

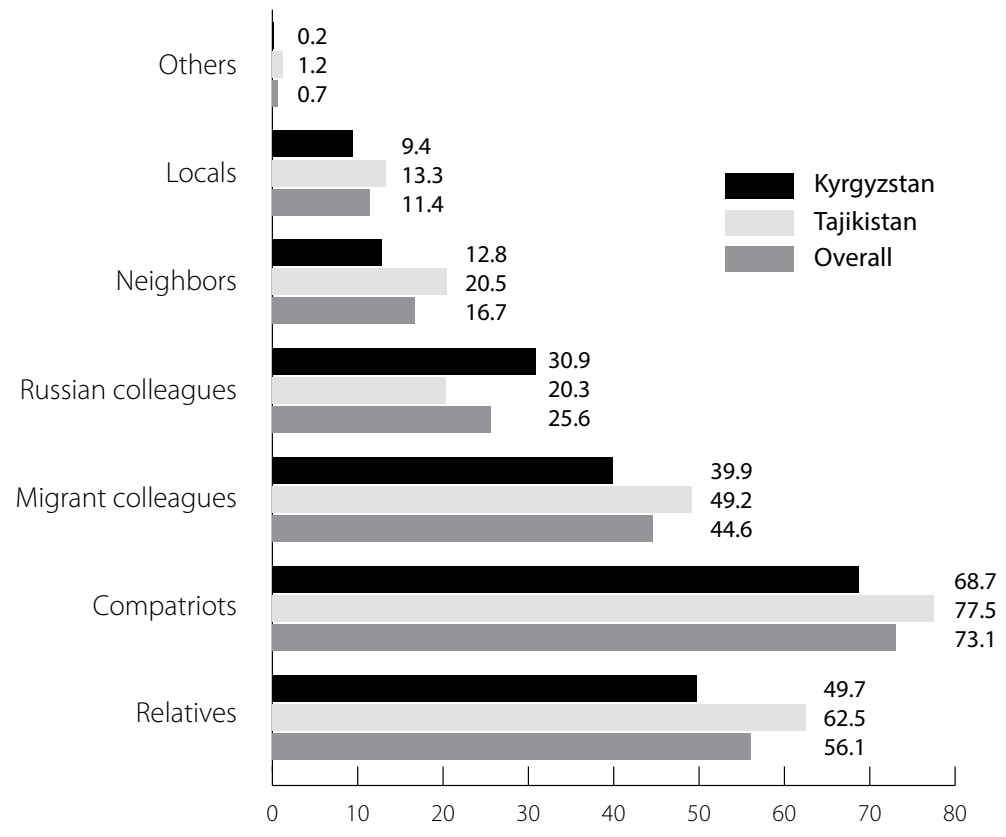

Source: Poletaev, et al., 2016

Even within the Muslim community, interaction between Muslim Russians and Muslim migrant workers from Central Asia is limited. Although the Tatar Muslim community and the Caucasus Muslim community welcome their fellow believers from Central Asia and seek closer relationships with them, complete unity is a distant prospect (Bukhari-zade, 2015). Interestingly, even the language of sermons in mosques located in big Russian cities has changed from Tatar to Russian, as migrant workers from Central Asia, who now make up most of the ummah, do not understand the Tatar language in which sermons used to be delivered. Some migrant workers from Central Asia have introduced elements of paganism into traditional Islam, such as "charging" water and using it for medicinal purposes (which 
is popular with part of the Kyrgyz community), new rituals that are at odds with the canons of Islam (divorce over the phone by repeating the word "talaq" (divorce) three times), and entering into marriages with the help of mediators without an official ecclesiastical title despite the fact that one or both partners are officially married back home in Central Asia. This creates mistrust and even some division between Russian Muslims and Muslim migrant workers from Central Asia.

Radicalization of migrant workers, even those who eventually obtain a residence permit or Russian citizenship, is one of the consequences of such disunity. Migrant workers and Russians of foreign origin-who are humiliated by xenophobia, do not have much education, and find themselves isolated from the Russian society for whose benefit they work tirelessly-provide fertile ground for spreading radical ideas, recruiting new members into terrorist organizations, and enlisting people for terrorist acts. On April 3, 2017, there was a terrorist attack on the St. Petersburg underground (Rozhdestvensky, et al., 2017). According to the Russian Investigative Committee, a suicide bomber by the name of Akbarjon Jalilov, an ethnic Uzbek born in Kyrgyzstan and a Russian citizen since 2011, was responsible for the blast that killed 16 and injured 87.

\section{THE GLASS WALL BUILT BY RUSSIANS}

Fear of migrants is the main "building material" for the wall being erected by part of Russians. While its level had slightly declined by 2018 (Poletaev, 2018b), it remains fairly high. According to the Levada Center (Levada, 2017), in 2017, the share of Russians wishing to limit the number of people of other ethnic backgrounds living in the country was $54 \%$, the lowest level in 13 years of sociological surveys, compared to $70 \%$ in 2016 and $81 \%$ in 2013. Attitudes towards members of the majority of ethnic groups living in Russia have improved. In 2013, $45 \%$ of the respondents believed that it was necessary to limit the presence of people from Central Asia in Russia. By 2014, the figure had dropped to $29 \%$ and reached $22 \%$ in 2017. Similar dynamics can be observed with regard to Roma, Chinese, Jews, Vietnamese, and Ukrainians. In 2017, the number of 
the Russians opposing restrictions on the number of residents of any non-Russian ethnic background in the country increased to $28 \%$, compared to $11 \%$ in 2013 and $20 \%$ in 2016.

Despite the slightly improved attitudes towards migrants, a majority of Russians (58\%) in 2017 (Levada, 2017) believed that their entry into the country should be limited, a 10\% decline from 2016. The attitude of Russians to migrants already living in the same cities was mostly neutral in 2017, with $60 \%$ of respondents saying they had no negative feelings about it. At the same time, $8 \%$ of respondents said they felt respect and sympathy for migrants, $28 \%$ expressed annoyance and hostility, and 2\%, fear (Levada, 2017). And yet, the level of xenophobia had started to rise again by the middle of 2018 (Levada, 2018).

The author's studies (Poletaev, 2014a) also show that Russians are considered fairly open to migrants, and this is according to migrant workers from Central Asia themselves (see Fig. 3).

Fig. 3. The Attitude of Local Residents to Migrants from Tajikistan and Kyrgyzstan, \% (2016, $\mathrm{N}=1001)$

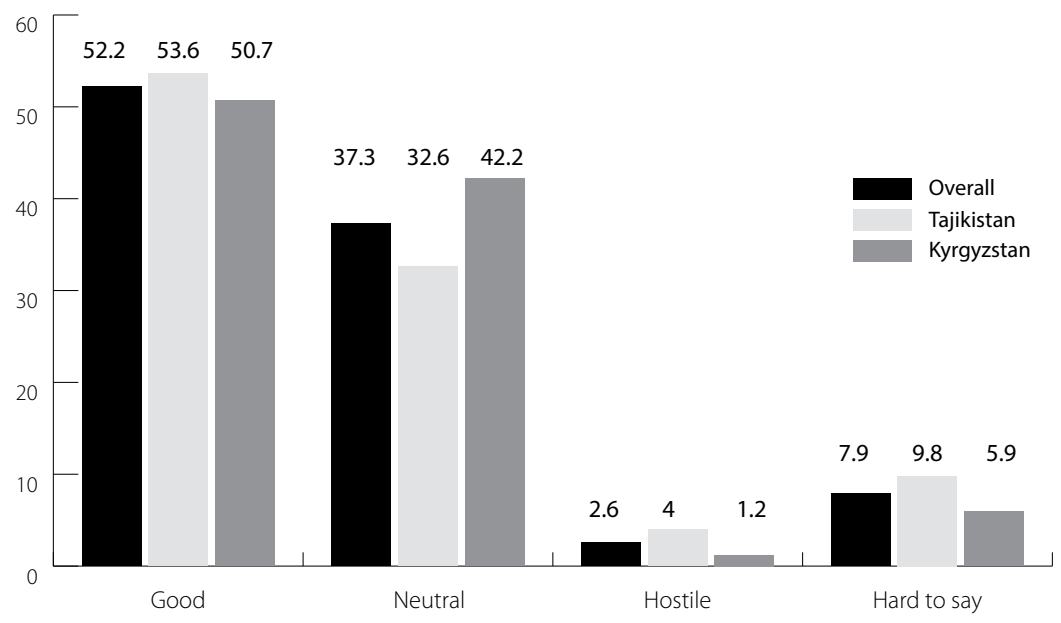

Source: Poletaev, 2014a

Lack of comprehensive and specially funded adaptation and integration programs for including migrants in the social and cultural life of Russian society and providing general assistance to them in 
Russia also contributes to building barriers between the local Russian population and migrants. In Russia, there are only isolated elements of an incomplete system to promote integration, such as free education for children of migrants at Russian schools, free emergency medical care, and free maternity hospital services for migrant women (Poletaev, 2011; Poletaev, et al., 2018). These elements are not interconnected and are not part of the country's migration policy. Moreover, they are not specifically aimed at reducing disunity between migrants and Russians.

Back when the Federal Migration Service of Russia was still in existence and to this day, the practice has been primarily to engage diaspora associations as the sole representatives of migrant communities in public dialogue and cooperation with the authorities of all levels. On the one hand, this decision excludes Russian NGOs that provide direct assistance to migrants of various categories from full-fledged cooperation with the authorities, but, on the other hand, it engages ethnic and cultural associations (diasporas) in the migrant adaptation and integration process, even though originally they were created not for migrants' adaptation and integration, but for the preservation of ethnic culture, traditions, and native language (Poletaev, 2016b). Roundtables with the participation of ethnic and cultural associations held by government officials and the involvement of such associations in the work of regional public chambers and the Civic Chamber of the Russian Federation is important and necessary, but only minimally effective in integrating migrants. Some diaspora associations monetize their interaction with the local authorities, providing migrants with fee-based legalization services. This state of affairs serves only to perpetuate the isolation of migrants in Russian society and complicates their basic adaptation and further integration.

\section{THE ROLE OF NON-STATE MIGRATION POLICY ACTORS IN FORGING SOLIDARITY WITH MIGRANTS IN RUSSIA}

\section{Non-profit organizations}

In the EU and the United States, as well as Southeast Asia, host countries have a large number of NGOs (Bolshova, 2012; Korobkov, 2015) that 
provide a variety of services to migrants. What sets them apart from Russian NGOs is that they are an integral part of the migration system of these countries and influence migration policy in their respective states and regions.

The small number of NGOs (RSMD, 2013) that provide the necessary assistance to migrants in Russia for free is due to both weak civil society and the lack of sufficient state funding for NGOs, including think tanks. Temporary projects of international organizations and grants from charitable foundations are too limited and inconsistent to ensure proper functioning and development. In addition, civil society institutions themselves as well as volunteering and social responsibility are not yet fully developed. However, there is a desire to consolidate and unite the efforts of NGOs in the form of creating special NGO networks and public organizations, including the All-Russian Memorial Network Migration and Law, which operates through lawyers (refugee.memo, 2019), and attempts to unite people on a broad civil platform like the initiative of the 21st Century Migration Foundation (Postavnin, et al., 2013) in late 2012.

Non-profit NGOs, such as Civic Assistance, Migration and Law, Sisters and the Ural House, to name a few, are more efficient than others at helping migrant workers. Unfortunately, their effective solutions for Russia have not yet been realized because the Russian state has not ordered the creation of services that are so vital to helping migrant workers.

In Russia, there are examples of migrant groups self-organizing as non-governmental organizations both for addressing long-term issues and providing relief for refugees experiencing catastrophic consequences of war. For example, the Forum of Migrant Organizations was created after the collapse of the Soviet Union to address the problems of refugees and internally displaced persons, and one of the many organizations that were part of this network-the Ural House-turned into a public organization that provides high-quality services to migrants at the lowest possible price. It operates according to strict ethical standards that preclude dubious schemes with shady intermediaries and has become a benchmark for the quality of service. 
The functioning of the Ural House Integrated Support Centre for Migrants makes it possible to simultaneously provide information, legal advice, accommodation, legalization services, and job placement for migrants; maintain feedback with migrants and employers; and create a database of potential migrants from the CIS countries and vacancies in the Sverdlovsk Region.

Russia has several large interethnic entities, such as the Federation of Migrants of Russia (FMR, 2019), the Assembly of the Peoples of Russia (Assambleya, 2019), and the Union of Diasporas of Russia, but their activities do not involve the provision of comprehensive direct assistance to migrant workers. Importantly, the migrant organizations that are now helping migrant workers (once united under the auspices of the Forum of Migrant Organizations, such as the Ural House, etc.) initially helped people of different ethnic backgrounds and mixed families leaving for Russia and did not divide migrants along ethnic lines. Disadvantaged migrants have always been for them more than just clients, but also supporters and allies. Precisely this strategy led to the current success of the civil society organizations in Russia when they have to fight for survival. People who found themselves in a new environment and a different country united to address common challenges, realizing what was proclaimed as a goal back in the Soviet Union: a multicultural society in which ethnic background is not important.

\section{Diaspora organizations}

Migrant diasporas in all Russian regions are unofficial and unstructured assistance organizations. There are quite a few of such diaspora organizations registered in various legal forms (mdn.ru, 2019), such as public organizations, ethnic and cultural associations and foundations. However, intermediary and commercial activities account for much of their work. High trust levels shown by migrants with regard to those who speak their native language have in some cases led to legalization schemes through unofficial channels with intermediaries using corrupt connections, relegating legalization services to the shadow economy. Russian intermediary commercial 
organizations and NGOs find it difficult to gain the trust of migrants, but diaspora organizations have no problem with that. They speak the same language, so turning a prospective client into an actual client is simple enough for them (Poletaev, 2016b). When such diaspora organizations deal with social problems of migrants and defend their rights, they succeed by protecting migrant workers from being cheated by unscrupulous employers, helping them escape slave labor or return home, etc. Unfortunately, a significant portion of them work on the market of intermediary services, and even if they call themselves a non-profit organization, they, in fact, are making money by helping migrants. Many diaspora representatives are interested in promoting commercial assistance among migrants, and such fee-based assistance is provided most often through commercial companies that are created to cater to such diasporas.

The diaspora organizations that are trying to provide free social services to migrants remain operational as long as they have funding, such as grants. As soon as they run out of funding, their work tapers off and other organizations, trying to fill the niche of the main representative of a particular diaspora in the region, quickly push aside the former protagonist. In their rivalry for leadership and clients within the diaspora, those who establish the best contacts with the consulate of the country of origin and the Russian authorities usually have the upper hand, which hampers consolidation of a diaspora.

Precisely because the diasporas operate through businesses engaged in fee-based intermediary activities that have their own financial interests, the attempts to unite diaspora organizations have so far been unsuccessful. It is also important to take into account the fact that diasporas are separated regionally, which is not good for unification either.

Activities such as providing free employment services, document issuance, talking with government officials, and defending the rights of migrants on a case-by-case basis are carried out haphazardly within diasporas. Not all diaspora organizations use lawyers in their work. As a rule, the leaders have to do the bulk of the work themselves, such as maintaining dialogue with the authorities and speaking at conferences. 
This prevents diaspora organizations from conducting any human rights activities to help migrant workers within the system.

The "old diaspora" organizations have been working in Russia for a long time now and quite intensively. These include the Armenian diaspora which runs Sunday schools and television broadcasts, and the Azerbaijani diaspora which has its own media. These diasporas are headed by rich and influential leaders. However, among migrants from Central Asia, only migrants from the Pamir Mountains have come up with a similarly strong organization.

\section{International organizations}

International organizations, such as the International Organization for Migration, the International Labor Organization, the United Nations High Commissioner for Refugees, Red Cross and Red Crescent, the International Centre for Migration Policy Development, etc., do an enormous amount of work to provide information and legal advice, to initiate public and academic discussions about migrant workers' problems and the help they need, and to share best practices in protecting the rights of migrants in Russia and around the world. International organizations have accomplished much. Their status allows them to influence the processes of forming systemic protection of migrant workers' labor rights and improving law enforcement practices, but they cannot participate in them directly. Thus, their role is important, but limited.

International organizations are most effective as coordinators of migration policy, consultants supporting NGO networks, and producers of analytical documents on important matters. As coordinators of new initiatives and best practices, they are effective in building a systemic approach to assisting migrant workers.

They can also spearhead initiatives to promote solutions to the most challenging problems, such as human trafficking (organizing shelters) and slave labor. In addition, by disseminating the best practices already developed by human rights organizations, NGOs, and commercial organizations, international organizations can help develop interaction models and spread them across Russia and the world. 


\section{Migrants' trade unions}

Labor migration is seen not only as a globalization trend, but even as an alternative to the class struggle (Milanović, 2011); therefore, the question of the most effective practices that migrant workers can use to protect their labor rights is becoming increasingly important. Studies show that migrants prefer to resolve their problems themselves, so the form of self-organization as trade unions looks most promising and straightforward to them, which is backed up by the existing practice of unions working with foreigners in Russia and around the world. However, trade unions in Russia and the rest of the world play very different roles when it comes to protecting migrant workers' rights.

For example, in Moscow, the Trade Union of Migrant Workers mediates labor disputes between migrants and their employers and provides high-quality services, information, and counselling to migrants. Its activities are not limited to intermediary services as it also publishes the newspaper Vesti Trudovoi Migratsii (News of Labor Migration) and informs migrants and their leaders about the latest changes in legislation and other developments. The upside of this union is that it has managed to demonstrate that trade unions can effectively work with migrants in Russia. Unfortunately, this union has so far been unable to encourage migrant workers to form a full-scale association and has only approximately 35,000 members on its roster.

Officials in Moscow, as the capital of Russia, cannot afford to be overly conservative. The situation in regions is more complicated. Local officials are more conservative, and it is therefore very difficult to create an active trade union there, especially a union for migrants. There have been attempts to create unions that are similar to the Migrant Trade Union. However, in the Urals region, for example, they ended unsuccessfully. On the one hand, this was due to the fairly large number of existing intermediary organizations in the region, and, on the other hand, the consolidation of migrants around a trade union was a delicate proposal since each of the diaspora organizations operating in the region pursued its own interests, primarily, financial ones.

There was an attempt to establish a Territorial Trade Union of Employees of Organizations Using Migrant Labor in the Arkhangelsk 
Region in 2008. However, according to the Sova Center (Sova, 2011), local authorities opposed the activities of this trade union, and it essentially closed down.

Not all countries have functioning migrants' trade unions. In some states the authorities do not allow such unions or restrict their activities. For example, a labor union of migrants in South Korea experienced strong pressure (iuf, 2007). There is the All-Ukrainian Union of Migrant Workers in Ukraine and Abroad (Migrant, 2019), which works with its members living and working outside the country.

Russian trade unions that have their origin in Soviet unions, as a rule, oppose labor migration and the very idea that Russia needs migrants. Such trade unions can hardly be considered partners when it comes to protecting migrant workers. Migrants never join these unions; such unions do not work with migrants or their employers. Their position as de facto opponents of cooperation with migrants has remained unchanged for quite a long time now.

In other countries, solidarity with migrant workers is based on a more comprehensive and broader foundation. For example, in the United States, the American Federation of Labor and Congress of Industrial Organizations (AFL-CIO) (Aflcio, 2019), has a partnership agreement with the network association of temporary workers-the National Day Laborer Organizing Network. This network operates through job centers throughout the U.S. and works with migrant workers who do not have a full-time job and are often employed without labor contracts. This association is not a trade union in the conventional sense, since it does not engage in collective bargaining. However, temporary workers use it to determine the rules and terms of employment, in particular, the minimum wage below which they cannot go. Most of the temporary workers and the majority of the job center employees are immigrants; therefore, they develop political, legislative, and legal rules that also affect migrants. There is also a partnership with another network job center called Interfaith Justice (Interfaith Justice Coalition, 2019).

The AFL-CIO Executive Committee in Chicago adopted a resolution that allows job centers to join trade unions at the local 
and state levels as public partners (Central Labor Councils/State AFL-CIO). There is a practice of preparing migrant workers for life far from home by involving them in union activities even before they leave their own country to migrate (ILO, 2008). For example, Belgian unions promote dialogue with trade unions in the countries of origin by organizing seminars and setting up information centers, while French trade unions have offices in the migrants' home countries in order to provide information on their rights and union membership.

Trade unions in countries of origin are also interested in maintaining contacts with members of their associations who have gone abroad, such as the National Union of Autonomous Trade Unions of Senegal (UNSAS), the Dominican National Labor Confederation (Confederación Nacional de Trabajadores Dominicanos, CNTD), the General Federation of Nepalese Trade Unions (GEFONT) with branches for Nepalese workers who work in India, the Ceylon Workers' Congress of Sri Lanka, the Moroccan Labor Union (Union Marocaine du Travail, UMT), and the General Confederation of the Portuguese Workers (CGTP-IN), which enlists migrants in the union in the countries of origin. Trade union associations in the countries supplying labor force develop policy measures to help migrant workers when they return to their respective home countries.

The Farm Labor Organizing Committee (FLOC) operates in the U.S. and Mexico (FLOC, 2019) ensuring the protection of agricultural workers and their participation in the union. In Mexico, FLOC advocates for the newly acquired rights of workers that farmers bring to the United States.

A global union federation-the Union Network International (UNI)-issued a UNI passport (UNI Global Union, 2019) to help migrant workers protect their trade union rights and receive assistance when moving from country to country.

Getting new members aboard is an important rationale behind enlisting migrant workers in unions. Labor market reforms in developed countries have led to a reduction in the number of trade unions, an increase in union members' average age, and a decrease in the number of trade unions in highly active industries. Given 
these circumstances, the search for new members in areas outside the scope of trade unions, including areas where migrant workers are employed, becomes important for strengthening the labor movement. For instance, in Switzerland, foreign-born workers already make up more than half of the Industry and Construction Trade Union (GBI) members. Meanwhile, Portuguese migrants join unions in the UK. Many new members who have joined the AFL-CIO after an extended period of shrinking union membership in the United States are migrant workers from Latin America and the Caribbean.

German trade unions cooperate with Polish unions in the construction industry and agriculture. They have offices in Warsaw where members can get information about employment terms and conditions and labor rights in Germany. Potential migrants in Poland are invited to join the union before leaving the country. The unions support bilateral and trilateral agreements between the migrants' countries of origin and destination countries which recognize the validity of joint union membership in both countries so that German unions can help migrant workers without them having to join their trade union.

In September 2004, the German Trade Union for Building, Forestry, Agriculture and the Environment (IG BAU) created the European Migrant Workers Union, which defends the interests of seasonal workers, especially migrant workers in the construction industry and agriculture (EMWU, 2019). The union provides legal assistance, advice, and support in the event of illness or accident, ensures the receipt of the agreed amount of compensation, and helps improve housing conditions. In the U.S., a number of Boston-based unions have developed the Immigration Rights Advocacy, Training and Education Project (RATE) with an eye towards uniting migrant workers, providing information and legal assistance and helping in creating workers' committees, as well as further training of trade union activists.

Even domestic servants, who are isolated from the host society and are subject to exploitation like no other workforce, such as the South African Domestic Service Allied Workers Union, are making efforts to 
unite. Unionizing domestic servants requires innovative strategies and approaches, as well as providing them with a wide range of services, such as help in overcoming low self-esteem and developing worker consciousness (SADSAWU, 2019).

Unfortunately, the above-mentioned practices of working with foreigners on the basis of trade unions still have very limited prospects for being implemented in Russia, which is due to the conservative stance of Russian trade unions and legal restrictions. However, efforts to protect migrant workers' labor rights are already underway as part of the EEU practices and have the potential to turn the situation around fairly quickly.

Summing up, the conclusions are as follows:

1. In major host countries, except Russia, despite the increasing popularity of right-wing parties in recent years and stricter migration policies, non-state actors supporting migrants (NGOs, trade unions, including migrant trade unions, international organizations, and associations dealing with migration policies and supporting migrants, to name a few) are strong enough to maintain the high levels of solidarity exhibited by host societies towards migrants.

2. In Russia, civil society had shrunk by 2019 and its actors operating in the field of migration are few and have limited resources. Migrants in Russia, as corroborated by studies, have minimal chances of getting support since integration and adaptation efforts on behalf of the state have been reduced to a minimum and the situation is unlikely to change any time soon. On the other hand, the state migration policy is being readjusted to stimulate the influx of migrants to Russia, which can provide the basis for creating, through state-run mass media, a more positive information background for solidarity with migrants.

3. The level of solidarity with migrants is fairly low in Russia today. However, civil society institutions have, since 1991, 
gained enough experience and developed practices to be able to effectively support migrants in Russia. As such, when migration policy is updated and its humanitarian component is improved, Russia will be well-positioned to enhance solidarity with migrants within its society.

Possibilities for forging solidarity with migrants in major host countries are changing. For example, the idea of open borders in the EU and the EEU are becoming increasingly multidirectional. EU countries, while preserving visa-free travel regime, discuss more and more often possible individual regulation and migration restrictions by member states within a common migration system (Poletaev, 2019). EEU countries, despite all the limitations and complications of building a common labor market, are contemplating further integration of their migration policies. In 2019 they have completed the discussion of measures to coordinate their pension systems for serving the needs of internal labor migrants in the EEU (Pertrov, 2019). In the current situation, one can say that the Eurasian migration system is growing stronger and has good prospects for further development as possibilities for rechanneling labor migration flows from EEU countries to EU host countries are dwindling.

The rise of right-wing politicians advocating migration restrictions in the EU and the U.S., on the one hand, and the modernization of migration policy in Russia, on the other hand (Ukaz, 2018; Solovyov and Samokhina, 2018), are changing the discourse on solidarity with migrants, making it more multifaceted but also controversial due to the growing role of non-state migration policy actors, the rising popularity of conservative views on migration in the EU and the United States, and an all-times low stability threshold for conservative views on migration in Russia.

It would be interesting to study further the evolution of migration restrictions which often defy human rights postulates enshrined in the legislation of host countries. Exploring the limits of progressing pragmatism (or populism?) amid emerging integration associations of both countries that supply and receive migrants, including 
coordination of migration policy, is likely to become an area which will arouse big interest among migration policy researchers.

Another promising area of research is the role of NGOs and other non-state organizations (such as trade unions and international organizations) in the future processes of forging solidarity with migrants in host countries, since the influence and viability of such actors depend, among other things, on state funding, but the approach of host countries and their citizens towards migration regulation is changing.

\section{References}

Aflcio, 2019. [online] Available at: http://www. aflcio.org / [Accessed 17 February 2019].

Assambleya, 2019. Assembly of the Peoples of Russia. Available from: http:// ассамблеянародов.рф/ [Accessed 17 February 2019].

Baruah, N. and Cholewinski, R., 2006. Handbook on establishing effective labour migration policies in countries of origin and destination. Vienna: OSCE. p. 37.

BBC, 2015. The four key points from David Cameron's EU letter. BBC news, 10 November [online]. https://www.bbc.com/news/uk-politics-34779250 [Accessed 17 February 2019].

Bershidsky, L., 2017. One million refugees came. Here's what happened next. Bloomberg, 18 September [online]. https://www.bloomberg.com/opinion/ articles/2017-09-18/one-million-refugees-came-here-s-what-happened-next

Bolshova, N., 2012. Nemetskie nekommercheskie organizatsii na pomoshch migrantam [German non-profit organizations to help migrants]. Russian International Affairs Council, 11 April [online]. http://russiancouncil.ru/ analytics-and-comments/analytics/nemetskie-nekommercheskie-organizatsiinapomoshch-migrantam/

Bukhari-zade, N., 2015. Starye i novye musul'mane Moskvy: ostorozhnye otnosheniia [The old and the new Muslims of Moscow: cautious relations]. Fergana News, 26 January [online]. http://www.fergananews.com/articles/8383 [Accessed 17 February 2019].

Demintseva, E. and Peshkova, V., 2014. Migranty iz Srednei Azii v Moskve [Migrants from Central Asia in Moscow]. Demoscope Weekly, No. 597-598. 
Dudina, G. and Pushkarskaya E., 2018. Tsentrobezhnye tendentsii. Lideram evropeiskikh stran ne udayotsa dogovorit'sia o tom, chto delat's migrantami [Centrifugal trends. European leaders fail to agree on migrant policies]. Kommersant, 25 June [online]. https://www.kommersant.ru/doc/3668062 [Accessed 17 February 2019].

Dunaev, A., 2018. Liga u vlasti. Zhdet li Italiyu Katalonskiī stsenariii? [The League has come to power: Is Italy up for the Catalonian scenario?]. Carnegie, 8 June [online]. https://carnegie.ru/commentary/76554

EMWU, 2019. European Migrant Workers Union [online]. http://www.emwu. org/ [Accessed 17 February 2019].

FLOC, 2019. Farm Labor Organizing Committee. Available at: http://www.floc. com [Accessed 17 February 2019].

FMR, 2019. Federatsia Migrantov Rossii [Federation of Migrants of Russia]. Available at: http://www.fmr-online.ru [Accessed 17 February 2019].

http://russiancouncil.ru/analytics-and-comments/analytics/nemetskienekommercheskie-organizatsii-na-pomoshch-migrantam/ [Accessed 17 February 2019].

ILO, 2008. In search of decent work. Migrant workers' rights: a manual for trade unionists. International Labour Office. Geneva: ILO.

Interfaith Justice Coalition, 2019. Interfaith Justice Coalition. Available at: http://www.interfaithjusticesd.org/ [Accessed 17 February 2019].

Iuf, 2007. Deportatsia liderov Koreiskogo profsoyuza migrantov [Deportation of the leaders of Korean Migrants' Trade Union] 14 January [online] http:// www.iuf.org/cgi-bin/dbman/db.cgi? db=default\&uid=default \&ID $=4751 \& v i$ ew_records $=1 \& w w=1 \& r u=1$ [Accessed 17 February 2019].

Ivakhnyuk, I., 2008. Evraziiskaya migratsionnaya sistema: teoria i praktika [Eurasian migration system: theory and practice]. Moscow: MAKS Press.

Ivakhnyuk, I., 2018. Ekspertny analiz Kontseptsii migratsionnoi politiki [Expert analysis of the Migration Policy Concept]. Migrant.ru, 5 November. http:// migrant.ru/novosti-proekta-sobiranie-naroda-ekspertnyj-analiz-koncepciimigracionnoj-politiki/?fbclid=IwAR0Of6JmmfRn2nA1TdakhRsdbvcqhh6o4 WUplG-w4lZZzZMri_kGQezS8BY [Accessed 17 February 2019].

Kartsev, D., 2018. Tretya Fol'kspartai. Pochemu "Al'ternativa dlya Germanii" - eto nadolgo' [A third Volkspartei: Why 'Alternative for Germany' is here to stay], Carnegie, 17 May [online]. https://carnegie.ru/commentary/76183 [Accessed 17 February 2019]. 
Kashnitsky, D. and Demintseva, E., 2018. 'Kyrgyz Clinics' in Moscow: Medical Centers for Central Asian Migrants. Medical Anthropology: Cross Cultural Studies in Health and Ilness, Vol. 37, No. 5, pp. 401-411.

Klimovich, S., 2017. Right and far-right: What does the new Austrian government mean for Russia and the EU? Carnegie.ru, 18 January [online]. https://carnegie.ru/commentary/75124

Korobkov, A., 2015. Sotsial'ny eksklyuziv migrantov v mestnykh soobshchestvakh iz-za ogranichennogo dostupa $\mathrm{k}$ sotsial'nym uslugam i blagam [Social exclusion of migrants in local communities as a result of limited access to social services]. Migration Working Group, U.S.-Russia Social Expertise Exchange. Available at: http://usrussiasocialexpertise.org/sites/default/files/ Migration\%20Study\%20-\%20RU.pdf [Accessed 17 February 2019].

kremlin.ru, 2012. Prezident utverdil "Kontseptsiyu gosudarstvennoi migratsionnoi politiki Rossiiskoi Federatsii na period do 2025 goda" [The President endorsed the Concept of the RF Migrants' State Policy for the period until 2025]. 13 June [online]. http://kremlin.ru/events/president/news/15635

mdn.ru, 2019. Spravochnik Moskovskogo doma natsional'nostei po natsional'nym obshchestvennym obyedineniyam [Ethnic Public Associations Handbook of the Moscow House of Nationalities] [online]. http://www.mdn.ru/cntnt/blocksleft/ menu_left/sotrudnishestvo/noogr.html [Accessed 17 February 2019].

Levada, 2016. Intolerantnost' i ksenofobia [Intolerance and xenophobia]. Levada-Center press release, 11 October [online]. Available at: http://www.levada. ru/2016/10/11/intolerantnost-i-ksenofobiya/ [Accessed 17 February 2019].

Levada, 2017. Uroven' ksenofobii v Rossii dostig minimuma' [Xenophobia rates in Russia have hit a new low]. Levada Center press release, 23 August [online]. https://www.levada.ru/2017/08/23/uroven-ksenofobii-v-rossii-dostigminimuma/ [Accessed 17 February 2019].

Levada, 2018. V Rossii vyrosli ksenofobnye nastroyenia [Xenophobia sentiments have grown in Russia]. Levada Center press release, 27 August [online]. https:// www.levada.ru/2018/08/27/v-rossii-vyrosli-ksenofobnye-nastroeniya/ [Accessed 17 February 2019].

Migrant, 2019. migrant.org.ua [online] http://migrant.org.ua/ [Accessed 17 February 2019].

Milanović, B., 2011. Global inequality. Washington, D.C.: World Bank. Available at: https://openknowledge.worldbank.org/handle/10986/3583 [Accessed 17 February 2019]. 
Mirzayan, G., 2014. Prem'er iz trushchob [The slumdog primier]. Expert, No. 22 (901), 26 May [online]. http://expert.ru/expert/2014/22/premer-iz-truschob/ [Accessed 17 February 2019].

Mukomel, V., 2012, Transformatsiya trudovoi migratsii: sotsial'nye aspekty [Transformation of labor migration: social aspects]. In: Gorshkov, M. (ed.) Rossiia Reformiruiushchayasia, No. 11. Moscow: Novy Khronograf, pp. 236-263.

Pécoud, A. and Guchteneire, P., 2007. Migration without borders. Paris: UNESCO Pub.

Petrov, A., 2019. Ostalos' podpisat' [All that is left to do is to sign the document]. Rossiiskaya Gazeta, No. 25(7783), 6 February [online]. https:// rg.ru/2019/02/06/zavershilos-obsuzhdenie-proekta-soglasheniia-o-pensiiahtrudiashchihsia-eaes.html?fbclid=IwAR0h70BzoMtfulrlYyjrcndEwjFt7Ey4n9S rFxiloB_dDHW9zflRG-PTx_Q [Accessed 17 February 2019].

Poletaev, D., 2010. Migratsia i grazhdanstvo [Migration and citizenship]. Levaya Politika, No. 10-11, pp. 116-123

Poletaev, D., 2011. Problemy detei migrantov v moskovskikh shkolakh [Problems of migrant children in Moscow schools]. In:Zhenshchiny-migranty iz sntran SNG $v$ Rossii [Women migrants from CIS countries in Russia], Moscow: MAKS Press, pp. 78-98.

Poletaev, D., 2014a. Migrantofobia i migratsionnaya politika [Migrant-phobia and migration policy] In: Migranty, migrantofobia i migratsionnaya politika [Migrants, migrant-phobia and migration policy]. Moscow: Academia, pp. 5-19 Poletaev, D., 2014b. Issledovanie o vozmozhnostiakh integratsii lits, priznannnykh bezhentsami v Rossiiskoi Federatsii [A study of the opportunities for integration of persons granted refugee status in the Russian Federation]. United Nations High Commissioner for Refugees [online]. http://www.unhcr.ru/ index.php?id=10\&tx_ttnews[tt_news] $=467 \& \mathrm{cHash}=182 \mathrm{a} 3546 \mathrm{e} 35 \mathrm{e} 8354 \mathrm{f} 5 \mathrm{~b} 07$ 13f3f660bla [Accessed 17 February 2019].

Poletaev, D., 2016a. Feminizatsia soobshchestv trudovykh migrantov iz Srednei Azii: novye sotsial'nye roli tadzhichek i kirgizok [Feminization of the labor migrants' communities from Central Asia: new social roles of Tadjik and Kyrgyz women]. In: Transnatsional'nye migratsii i sovremennye gosudarstva $v$ usloviyakh ekonomicheskogo krizisa [Transnational migration and modern states in the conditions of the economic crisis, RSMD. Available at: http:// russiancouncil.ru/common/upload/сборник_Транснациональные\%20 миграции.pdf 
Poletaev, D., 2016b. Izmenenie praktik povedenia trudovykh migrantov iz Srednei Azii v Rossii. [Change in the behavior of labor migrants from Central Asia in Russia]. In: Vostok na Vostoke, Vostok na Zapade $i$ Vostok $v$ Rossii: migratsia, adaptatsia, identichnost' [The East in the East, the East in the West, and the East in Russia: migration - adaptation - identity]. Moscow: Institut Vostokovedenia RAN.

Poletaev, D., 2016c. Migratsia i voprosy kvalifikatsii v Severnoi i Tsentral'noi Azii [Migration and qualification issues in Northern and Central Asia]. ESCAP. Available at: https://www.unescap.org/sites/default/files/2\%20Migration\%20 and\%20Skills\%20Rus\%20report\%20v1-4-E_0.pdf [Accessed 17 January 2018].

Poletaev, D., Nasritdinov, E., and Olimova S., 2016. Analiz konyunktury rynka truda $v R F v$ tselyakh effektivnogo trudoustroystva trudiashchikhsia migrantov iz KR i RT [Russian Labor Market Analysis for Effective Employment of Labor Migrants from Kyrgyzstan and Tajikistan]. Bishkek. Available at: http://www. fergananews.com/archive/2017/Report_Book_Final_version_Rus_02_2017. pdf

Poletaev, D., 2017. Rastrata kompetentsiy trudovykh migrantov v Rossiiskoi Federatsii: realii i perspektivy [Loss of competence by labor migrants in the Russian Federation: reality and prospects. Sotsialnaya politika $i$ sotsiologia, Vol.16, No. 1(120), pp.133-140. Available at: http://rgsu.net/about/science/ publishing/magazine/2017SP/2017SP_2521.html

Poletaev, D., 2018a. Zhenskaya trudovaya migratsia iz Tadzhikistana i Kirgizii v Rossiyu [Women labor migration from Tajikistan and Kyrgyzstan to Russia]. Narodonaselenie, Vol. 21, No. 4, pp. 68-78.

Poletaev, D., 2018b. Ot nastorozhennosti k nepriyazni: dinamika otnoshenia v Rossii k transgranichnym trudovym migrantam v 2002-2016 gg. [From apprehension to enmity: change in the attitude of Russians to transnational labor migrants in 2002-2016]. In: Panarin, S. (ed). Ot veka bronzovogo do veka tsyfrovogo: fenomen migratsii vo vremeni [From the Bronze Age to the Digital Age: the phenomenon of migration in time]. Barnaul: Altai State Institute, pp. 267-284. Available at: https://book.ivran.ru/f/fen-migr.pdf [Accessed 17 January 2018].

Poletaev, D., 2018c. Les travailleurs migrants face à la tuberculose en Russie et au Kazakhstan: résultats d'une enquête exemplaire. In: Hohmann, S., and Kurbanova, R., (eds). Santé et migration en Asie centrale, Cahiers d'Asiecentrale. Ed. Pétra, Paris, 28 January. 
Poletaev, D., Zaionchkovskaya, Zh. and Mikhailov, D., 2018. Problemy zashchity prav detei, ne imeyushchikh rossiiskogo grazhdanstava, v Moskve [Problems of the protection of the rights of children residing in Moscow, but not having Russia citizenship]. HR Ombudsman in Moscow, ROO “Tsentr migratsionnykh issledovaniy".

Poletaev, D., 2019. Global'ny prognoz 2019-2024. Global'ny prognoz po migratsii na kratko- $i$ srednesrochnuyu perspektivu. [Global forecast 2029-2024. Global forecast for migration for the short and long term]. Available at: http:// russiancouncil.ru/2019-globalissues?fbclid=IwAR1q1ZEGqNbn3gWBQlicwOWoAB_IvIHCRUdJvJ2jUIj8L98zYrlbSktRTc

Postavnin, V. et al, 2013. Zayavlenie liderov nepravitel'stvennykh organizatsiy, rabotaiushchikh v sfere migratsii [Statement of the leaders of NGOs operating in the sphere of migration], Migratsiya 21 Vek, No. 7(16), January-February, pp. 22-25.

Profmigr, 2019. [online]. http://www.profmigr.com/ [Accessed 17 February 2019].

refugee.memo, 2019. [online]. http://refugee.memo.ru/ [Accessed 17 February 2019].

Rozhdestvensky, et al., 2017. Chto izvestno o krupneishem v istorii goroda terakte [Factlist on the biggest terrorist act in the history of the city], $R B K$, No. 058 (2555) (0404), 3 April, St. Petersburg [online]. https://www.rbc.ru/new spaper/2017/04/04/58e2384a9a7947f3f0173629

RSMD, 2013. Handbook "Migration field of Russia." Russian International Affairs Council (RSDM). Available at: http://russiancouncil.ru/en/projects/ complitedpublishing/migration-directory/ [Accessed 17 February 2019].

Sadsawu, 2019. [online] http://www.sadsawu.com / [Accessed 17 February 2019].

Solovyov, V. and Samokhina, S., 2018. Rossiisky pasport podnyali povyshe. Vladimir Putin zamknul migratsionnuyu politiku na Admimistratsiyu Presidenta [Russian passport status has been raised. Vladimir Putin made Presidential Administration responsible for migration policy]. Kommersant, No. 237, 24 January [online]. https://www.kommersant.ru/doc/3841597?fbclid=Iw AR28_6aDeGTySYS16iCfTXVPcPngi-Bn-4jkXlwNPnQYHBJNQr5d1fpgiSs [Accessed 17 February 2019].

Sova, 2011. Profsoyuznaya deyatel'nost' kak nasil'stvennoye izmenenie osnov konstitutsionnogo stroya [Trade union activity as an attempt to forcefully 
change the foundations of the constitutional state system]. Tsentr Sova [Sova Center], 22 July [online]. http://www.sova-center.ru/misuse/news/ persecution/2011/07/d22173/

Strokan, S., 2014. Kasta natsionalistov. Vlast' v Indii perekhodit k "Bkharatiia Dzhanata Partii" [The nationalist caste: the Bharatiya Janata Party comes to power], Kommersant, 15 May [online]. https://www.kommersant.ru/ doc/2470280 [Accessed 17 February 2019].

Tyuryukanova, E., 2009. Trudovye migranty v Moskve: "vtoroye" obshchestvo [Labor migrants in Moscow: "second" society"]. In: Zaionchkovskaya, Zh. (ed.). Immigranty v Moskve [Migrants in Moscow]. Moscow, pp.148-175.

Ukaz, 2018. O Kontseptsii gosudarstvennoi migratsionnoi politiki Rossiiskoi Federatsii na 2019-2025 gody [On the Concept of Migration State Policy of the Russian Federation for the Period of 2019-2025]. Ukaz Prezidenta RF [Decree of the President of Russia], 31 October. Available at: http://kremlin.ru/events/ president/news/58986 [Accessed 17 January 2018].

UNI Global Union, 2019. UNI Passport. Available at: http://www. uniglobalunion.org/groups/managers-professionals/uni-passport [Accessed 17 February 2019].

UN, 2016. International migration and development. Report of the SecretaryGeneral. General Assembly A/71/296. Available at: http://www.un.org/en/ development/desa/population/migration/generalassembly/docs/A_71_296_E. pdf [Accessed 17 February 2019].

Zaionchkovskaya, Zh., et al., 2011. Trudovaya migratsia v Rossiyu: kak dvigatsa dal'she? [Labor migration to Russia: What to do next?]. Migratsionny barometr $v$ Rossiiskoi Federatsii [Migration barometer in the Russian Federation]. Moscow: MAKS Press.

Zaionchkovskaya, Zh., et al., 2014a. Domashnie rabotnki v Rossii i Kazakhstane [Household employees in Russia and Kazakhstan]. Almaty: Ex Libris.

Zaionchkovskaya, Zh., et al., 2014b. Zashchita prav moskvichei $v$ usloviyakh massovoi migratsii [Protection of rights of Muscovites in the face of massive influx of migrants]. Moscow: Commissioner for Human Rights in Moscow Region, Center for Migration Studies. 